\title{
MODERNiSM VS. MODERNITY: Katherine Mansfield as Critic
}

\begin{abstract}
Katherine Mansfield, just like many of her contemporaries, was uncomfortable with the dark side of modernity and its effects - the mass culture and consumerism, the commodification of everything, including art. Yet her example seems to support the belief that modernism is not a simple reaction against modernity, as it was sometimes presented, and that the relation between the two is far from uniformly antagonistic. For one, Mansfield openly distanced herself from highbrow attitudes and rhetoric and embraced the opportunities of the market, negotiating her place in the artistic world through both the publication of her stories in journals and becoming an editor and reviewer herself.

Looking more closely at Mansfield's rather neglected critical writings, this paper examines her own engagement with some of the predominant issues of her era, points out the similarities and differences between her and some of her more canonical contemporaries, and discusses her opinions concerning modernism and modernity in art and related questions of authenticity and tradition.
\end{abstract}

Keywords

Katherine Mansfield; literary criticism; modernism; modernity; literary market

Where does Katherine Mansfield belong? Literary historians have had a hard time deciding. For several decades it was customary to exclude her from the canon of modernism, or afford her only a fleeting mention. ${ }^{1}$ For many, she was simply unimportant; for others, most notoriously Frank O'Connor (1963) in his study of the short story The Lonely Voice, she had hogged the spotlight quite enough and needed bringing down to size. For still others, she was a colonial subject inhabiting a hybrid identity, and as such she did not fully participate in the 
"cultural mythology of England" that was central to so much British modernist writing (Garrity 2003: 5).

In more recent times, the interest in Mansfield has grown exponentially, undoubtedly also due to the publication of several crucial works inaccessible (in a reliable form) to scholars before - five volumes of letters edited by O'Sullivan and Scott (1984-2008), and her complete diaries edited by Scott (1997). The previously published letters and journals edited by her husband John Middleton Murry included so many elements of fiction and were so selective that much of the critical work had to be done anew. With this new wave of interest and with a large number of new scholarships focusing on her works, ${ }^{2}$ Mansfield's position within the canon has started to shift. However, while she became located much more centrally within the modernist fold, there remain telling deficits in the accounts of her work. One such deficit surrounds her critical writing, which, despite its considerable extent, has never been subject to the sort of attention afforded to Woolf's essays and reviews, for example. Certainly, Mansfield never engaged in systematic or large-scale reflections on art and culture in her essays, unlike Woolf or Eliot, or even her husband J. M. Murry. Dead by the age of thirty-four, and with years of debilitating illness and a necessity to travel for health reasons before that, she simply did not have time. But something more is at stake in the continuing marginalization of Mansfield as a critic and thinker, and it has to do, I suggest, with a concern Mansfield frequently expressed about herself, namely that she was not sufficiently intellectual in her opinions and interests. The early enthusiasm after her arrival in London in 1908 to start a literary career was soon tainted by defensive remarks in her letters and diaries suggesting her unease about her education and background in the face of Murry's intellectualism and the education of the Bloomsbury group. Her insecurity was probably also fuelled by Murry's obvious selection of inferior works for her to review and his failure to respond when she requested some major work.

More than that, she often took a position, particularly in her reviews for the Athenaeum, that set her at odds with her modernist peers. The critical review essay was, of course, a major instrument of modernist self-fashioning, and was used by Pound and others to present more or less covert manifestos for their own writing. By this measure, Mansfield failed the modernist litmus test, being susceptible to works that the "Men of 1914", Wyndham Lewis' label for Eliot, Joyce, Pound and himself, could be expected to deplore, and at times ambivalent about ideas they were eager to advance.

Little surprise, then, that for many years Mansfield's review of Woolf's Night and Day had to do service as the sole representative example of her critical writing. ${ }^{3}$ Of the many other review notices she filed, most fell under the modernist radar, being accounts of writers and writing of no great significance to the avantgardists. However, Jenny McDonnell has recently argued that it was through the review article that Mansfield undertook her own "reappraisal of fictional forms and conventions" (2010: 119). I want to suggest that her reviews tell us about more than just the evolution of Mansfield's own fiction. They are documents that 
take us to the heart of debates in this period about literary value, cultural prestige, and what Woolf would call the "custom" of fiction. And although Mansfield often beats up on the kind of fiction other modernists deplored, she did so with a slightly different emphasis and, what is more, sometimes even included her fellow modernists in the ranks of those they were so fiercely trying to detach themselves from.

Although Woolf would write warmly after Mansfield's death of her achievements, there is no doubt that she, along with T.S. Eliot, considered Mansfield to be treading a questionable line between the literary and the populist, at least while she was still alive. Her strong sales and visible presence in newspapers were sure signs, Woolf thought, of a lack of seriousness and pedigree:

So what does it matter if Katherine Mansfield soars in the newspapers, runs up sales skyhigh? Ah, I have found a fine way of putting her in her place. The more she is praised, the more I am convinced she is bad. After all, there is some truth in this. She touches the spot too universally for that spot to be of the bluest blood. (qtd. in Smith 2000: 2)

For Woolf, artistic excellence, like nobility, exists in small quantities, and its rarity is what ensures its continuing value. Mansfield was undoubtedly not one of those who went "in the heights of obscurity in order to avoid the common (Scholes 2006: 19);" yet it seems an exaggeration of Woolf's to suggest that she pandered to the market; an exaggeration that was fuelled by her own insecurity and jealousy rather than real dislike of Mansfield's work. Woolf herself did not think "the heights of obscurity" to be the ideal and even deplored this practice in Joyce and Eliot, claiming that Eliot

has written some of the loveliest single lines in modern poetry. But how intolerant he is for the old usages and politeness of society - respect for the weak, consideration for the dull. As I sun myself upon the intense and ravishing beauty of one of his lines, and reflect that I must make a dizzy and dangerous leap to the next (...) and [I] envy the indolence of my ancestors who instead of spinning madly through mid-air, dreamt quietly in the shade with a book. (qtd. in Scholes 2006: 116).

Although Woolf's put-down of Mansfield is, more than anything, her self-defence against the panic of being confronted with what she privately thought to be an equally good or even better writer, in general terms, for her the distinction line between quality and trash, at least in these early years of modernism, seems to have been clear - saleability; the general approval of the public clearly marked a bad writer.

In her private correspondence Mansfield often hinted at her position or the standing of her reputation among the Bloomsbury set. She wrote to William Gerhardi following his praise of Bliss and Other Stories: 
You know - if I may speak in confidence - I shall not be "fashionable" long. They will find me out; they will be disgusted; they will shiver in dismay. I like such awfully unfashionable things - and people - I like sitting on doorsteps, and talking to the old woman who brings quinces, and going for picnics in a jolting little wagon, and listening to the kind of music they play in public gardens on warm evenings ... But you see I am not a high brow. Sunday lunches and very intricate conversations on Sex and that "fatigue" which is so essential and that awful "brightness" which is even more essential - these things I flee from. I am in love with life - terribly. Such a confession is enough to waft Bliss out of the [library of the Oxford] Union... (Letters 4: 323, [21 November 1921])

Mansfield may have joined with the modernists and fauvists in their fetishization of primitivism and pre-industrial society (jolting wagons and the woman who brings quinces); yet her attribution of the term "fashion" to the coterie literary set reveals her distance from them, and her willingness to problematize questions of cultural value and prestige. Mansfield does not regard the intellectual elite as being immune to the allure of materialism and fashion - the very preoccupations Woolf famously condemned in her Edwardian predecessors most notably in "Mr Bennet and Mrs Brown".

The whole extract of the letter is a clear parody on Bloomsbury intellectualism and their discussions and the word "life" stands out. It is put in opposition to falsity and pretence of the intellectual coterie, and it is interesting to note that there is hardly any word (apart from "real") that Mansfield uses more often or with greater urgency in her reviews and personal writing. For her, any work of art has to be attached to it, draw from it or have a connection to it to be real and authentic. Woolf seems to be referring to a very similar concept when she talks about the "essential thing" in art "whether we call it life or spirit, truth or reality,"(Woolf "Modern Fiction": n.p.) yet elsewhere suggests the interpretations of the word might differ and subsequent results of its application in literature yield unsatisfactory results: "fiction is treated as a parasite which draws sustenance from life and must in gratitude resemble life or perish" (Woolf, "The Art of Fiction", n.p.). Woolf further claims that if literature detached itself from what the English literary critic calls life, the novel "might become a work of art" (Woolf, "The Art of Fiction": n.p.).

The concept of "life" being so broad and ambiguous, it might just be a simple misunderstanding, one of many which so famously surrounded their relationship and which, at closer scrutiny of their respective works, dissolves and shows that they really were "very nearly after the same thing" (Letters 1: 327; to Virginia Woolf, [c. 23 August 1917]). The relationship between the two writers is too complicated to discuss in this paper, and it has been done at great length elsewhere, ${ }^{4}$ but it is important to say that when left alone together they displayed a deep mutual understanding, and extraordinary kinship in their attitudes towards writing; however, the complicated dynamics of the Bloomsbury group, their "unthinking 
imperial snobbery" (Smith 2000: 1) (and some of their members' insatiable gossiping) as well the infrequent meetings caused by Mansfield's illness led to many misconstructions and offences that reflect indirectly in both their published and unpublished opinions. Misunderstanding seems to be, at least partially, also the case of the bone of contention concerning the position of brows, mentioned in the letter to Gerhardi.

Although Woolf's attack on middlebrows was published years after Mansfield's death, and more importantly, after her own too, the concept itself and Bloomsbury's attitude to it must have been common knowledge from much earlier. The fact that Woolf herself never published the essay indicates that she was not completely at ease with what she wrote, but it is useful to consider it for the purposes of this paper, because whether and how exactly she meant it or not is not as important as the fact that it corresponds with how Mansfield thought she was perceived and assessed by the "wolves" (Letters 1: 330; to Dorothy Brett, [11 October 1917]) and their associates.

Mansfield's reference to not being a "highbrow" can be read in two ways. First as a boast; she is distinguishing herself from those she identifies as sham. Yet, there is also something like regret, very similar to her self-defensive remarks mentioned earlier. Mansfield knows she cannot belong because just like being "of the bluest blood", being a highbrow, requires something one cannot very well influence one's birth and social standing. She is neither "riding across the country in pursuit of ideas" (Woolf "Middlebrow": n.p.), nor is she in pursuit of "real life" - that is, working manually and taking care of ordinary things. She has no birth, formal education and own financial means for the former, and no matter how she would want to wholly give herself to work, she is too well-educated and from a well-off family and could not (even if she wished to) pass for a simple woman. Her colonial status, the wealth of her family (yet not the right kind of wealth for the "Bloomsberries"), all speak against her. She is delegated to the category of "betwixt and between," those who want to or have to make concessions to the tastes of the reading public. Although Woolf's essay might be referring to the aristocracy of mind rather than to mere social standing, the previously quoted dismissal shows that even in that respect, Mansfield did not qualify, a belief which must have somehow been felt by Mansfield who was unaware of the other woman's secret admiration.

Yet it is not the first time that Mansfield proved she could be defiant in the face of all adversity. She rejects these preposterous limitations and the haughty rule of Bloomsbury ideology and systematically works to prove that the literary market and art can be reconciled. She will be vindicated, even if posthumously, by the massive market success and canonical status of the high modernists.

The following discussion of Mansfield's critical writings offers an insight into some of the most predominant issues she discussed in her reviews and is not comprehensive. Furthermore, in many ways she is in accordance with other modernists, particularly with Woolf, but as this aspect of her writing is not very well known, it seems important to present and analyse it in order to broaden the complex picture of modernist critical thinking. 
Mansfield refuses to adopt the stratification of artistic society into high- or middlebrows. Instead, it is "authenticity" that she is interested in, wheresoever it may be found. Her thinking, that is to say, is organised around a dialectic not of old vs. new, or traditional vs. modern, and certainly not intellectual vs. popular; it is, rather, the authentic in contradistinction to the inauthentic that concerns her, and in her reviews she gives equal praise to innovative ${ }^{5}$ and traditional works ${ }^{6}$ that succeed in "being attached to life". If they meet this requirement, they can have a lasting value and transcend their age and "fashion", (with the implication that "fashion" is as much a feature of the privileged squares of Bloomsbury as it is of the thoroughfares of consumerist London).

The kind of writing that lacks authenticity results in "modern" (understand derisively as fashionable) works that fail to achieve anything significant and become hardly more than a quickly perishable commodity, like freshly made buns:

"All Roads Lead to Calvary" is another novel. It is not more; it is one of that enormous pile of novels.... "Are they fresh?" "Yes, baked to-day, Madame." But they are just the same as those that were baked yesterday and the day before - and the day before that. So much flour, a sprinkle of currants, a smear of sugar on the top. Melancholy, melancholy thought of all those people steadily munching, asking for another, and carrying perhaps a third one home with them in case they should wake up in the night and feel-not hungry, exactly—but "just a little empty." $(C W 3: 560)^{7}$

Here Mansfield ingeniously draws a parallel between the market and the behaviour of consumers and the production of books; voicing the fears and anxieties of her generation facing the realities of their era of "economics in which waste, excess and mass consumption are central terms [and this] has important consequences for the arts" (Armstrong 2005: 3). Yet, while at first sight Mansfield's metaphor seems to suggest her rejection of the downgrading of art to the level of commodities, I would argue that the emphasis lies elsewhere: the crucial part is the final "just a little empty" leading one back to the question of authenticity. The problem Mansfield sees is not so much the "saleability" of a work of art but the purpose it serves once sold. Her metaphor clearly rejects consuming for consuming's sake, whether it be buns or books that do not feed hunger but just some unidentified sort of "emptiness"; she snubs a desire fed by custom rather than a genuine physiological (buns) or intellectual (books) need.

What is more the title of the double review is a little incompatible to the text, "The Stale and the Fresh", (it suggests that Klapka Jerome's book is stale yet the beginning of the review refers to fresh buns) and that can be understood as an important comment on popular literature. While Jerome Klapka Jerome's novel is nothing more than a stale bun, one to be munched at night when one feels a little "empty", Beatrice Kean Seymour's is a fresh bun, something clearly not in ranks of great literature but which nevertheless, has "hardy roots [...] [the author] ought to cultivate" ( $C W$ 3: 561) and is authentic and interesting in its own right. This 
and other reviews indicate that Mansfield was not so much at war with popular literature (as many of her contemporaries) but with pretentious and insincere production no matter which camp it belonged to.

Mansfield is swift in recognizing and uncovering the formulaic works which are trying to "feed" on an already successful pattern, whether it be a traditional or an experimental one. In the reviews of such works Mansfield obviously suggests that these writers do not write from their heart but look around for the best-selling (in the case of traditional novels) or most fashionable techniques and topics (in the case of experimental ones) and use them as a password to the world of publishing or intellectual circles. Although the former is obviously closer to the definition of a market and its strategies with its direct connection to financial benefits, the other, although not bringing money, can function in the same way yet bring other kinds of benefits. Thus Mansfield implies that there is another kind of market, the one "which decides the value of literary and artistic works" (Bourdieu 1984: 91) and which does not deal with money but with recognition and esteem in a highly selective group of those who consider themselves true artists as opposed to the masses.

The traditional kind is best illustrated in the review of Arthur Weigall's Madeline of the Desert, which she characterizes as a novel "that never was new - a new carriage hitched on to the same old engine, making the same journey, stopping at the same stations and running into the same sunset" $(C W 3$ : 607). She further notes that the writer should "free himself from the idea that a novel is not furnished if it does not contain all the furniture mentioned in all the catalogues" ( $\mathrm{CW}$ $3: 607)$. The furniture catalogue is yet another of the number of market metaphors Mansfield uses and it beautifully serves her purpose of identifying the techniques and topics deemed necessary for success in either market, whether the financial or the intellectual one.

Nowhere is this "catalogue" tendency more visible than on the works that deal with the pet topic of the post-war era, the Great War itself. ${ }^{8}$ From all the novels Mansfield was reviewing, a great number dealt with the war and only two reviews were positive. In most cases Mansfield again uncovers the superficiality, falsity and pretence of these works. Taking her furniture metaphor further, some of the books are inspired by the old "country house" furniture catalogues full of good old wooden tables and wardrobes, never really in fashion but also never out of it: those are the old war-connected myths about war being the cleansing fire and a means of making men out of boys. She even sardonically renames it "the greatest of all garden parties" ( $C W$ 3: 511) mocking the early 1914 enthusiasm that, unbelievably, some retained even after the war ended.

She notes that like Mrs. Victor Rickard's The House of Courage, many novels follow one pattern and even when the topic is, understandably, frequent, there is "in [the] treatment of it, [no] variation with which we have not become familiar during the past four years" ( $C W 3: 445)$.

Another kind are those that take their furniture out of top modern catalogues, speaking about shell-shock, the trauma of the war and the disruption of values, 
and that even in experimental form, but yet again with no trace of it touching deeper than the surface, are merely being "fashionable". Their characters, even if for a time experiencing the atrocities of the conflict, return to their pre-war lives untouched or at the utmost, "more sober" (CW 3: 445).

Mansfield connects this inability to keep up with the newness of the era with the lack of memory which she so famously deplores in both Dorothy Richardson and Virginia Woolf. She suggests that whether a war novel or not, no post-war writing should be the same as it was before it; reflecting the changed situation in what she refers to as a "new mould", that is, a new form of writing. In her letter to Murry she claims that after the war: "nothing can ever be the same - that, as artists, we are traitors if we feel otherwise: we have to take it into account and find new expressions, new moulds for our thoughts and feelings" (Letters 3: 82, [10 November 1919]).

Interestingly, her analyses of the techniques of the novels often lead to paradoxical, or at least seemingly paradoxical, conclusions with respect to what is known about her own art and techniques. Much has been written about Joyce's epiphanies and Woolf's "moments of being" with respect to the modernist aesthetics. Mansfield's own version of these, referred to by herself as "glimpses", certainly puzzle one when reading her joint review of Ethel Colburn Mayne's Blindman, Eleanor Mordaunt's New Wine in Old Bottles and Dorothy Richardson's Interim, quite aptly entitled "Dragonflies" $(C W 3$ : 556-558).

In this review Mansfield compares the technique of some writers to the flight of a dragonfly who unexpectedly interrupts its "swift angular flight" to "suddenly pause and hover, quivering over this or that[.] The strange little jerk - the quivering moment of suspension - we might almost fancy they were the signs of a minute inward shock of recognition felt by the dragonfly" ( $C W 3: 556)$. Yet in a little while, the dragonfly is away, its attention caught by something else and "again it is still, curious, hovering over. ..." Mansfield observes that although this behaviour is enchanting in the dragonfly, it certainly is not adequate for the writer of fiction.

Nevertheless, there are certain modern authors who do not appear to recognize its limitations. For them the whole art of writing consists in the power with which they are able to register that faint inward shock of recognition. $(C W 3: 556)$

So far, Mansfield's description of the technique she condemns in her contemporaries is thoroughly in line with "epiphanies," "moments of being" or her own "glimpses" which could quite easily be defined as "inward shocks of recognition". Yet there is a further explanation of what she believes to be the flaw of this approach and where the difference lies.

But now, instead of going any further, instead of attempting to relate their "experiences" to life or to see them against any kind of background, these 
writers are, as we see them, content to remain in the air, hovering over, as if the thrilling moment were enough and more than enough. ( $C W 3: 556)$

Mansfield seems to condemn such writing as empty: the author is registering surface impressions from a distance, not daring or wishing to approach closer, and that metaphorically disables him or her from seeing through the tricks and illusions of light. What is more, both Woolf and Mansfield understood their "moments of being" as gates to some higher knowledge, as glimpses of a larger pattern transcending the experience of one particular human being and connecting it to the experience of other people. The "inward shocks of recognition" Mansfield is criticizing have no such quality, they are mere observations, and the writer stops short of attaching any deeper meaning to them. Mansfield is firmly persuaded that writer's mission is not to answer questions championing the aesthetics of absences; her absences are, nevertheless, meaningful, related to life, uncovering the truth hidden deeper - the truth that does not give itself away at first sight.

For all the cases, where the pattern (whether the old or the new one) prevents the writer from doing more than slipping on the surface and often becomes the end rather than the means, Mansfield aptly uses a category of "pattern mongers" for those who do not give her the feeling that "all this beauty is in the deepest sense attached to Life. Real Life!"(Letters 4: 270; to Dorothy Brett, [29 August 1921])

Yet the opposite extreme is no good either. There are also those for whom there is either no pattern at all or they forget it as soon as they start writing.

we have not seldom remarked the curious naïve pleasure that many women take in writing for writing's sake (...) But it is a dangerous delight, for what so often happens is that they are quite carried away, forgetting all about the pattern they intended to follow or embroidering it so thickly that none but themselves can discover its original outline. ( $C W 3: 527)$

While Mansfield firmly believes that the newness of the era and its "disintegrating spirit" (Smith 2000: 121) requires new ways of writing, she does not think all the rules should be destroyed, they just have to be redefined and adjusted to the new reality. She rejects what, according to her, some writers understand as an endless freedom to ramble - having no pattern whatsoever, no restrictions or rules. And her criticism is not limited to the second-rate production of her times; she tackles even Gertrude Stein in her review of Three Lives, entitled suggestively "Some New Thing":

Miss Gertrude Stein has discovered a new way of writing stories. It is just to keep right on writing them. Don't mind how often you go back to the beginning, don't hesitate to say the same thing over and over again - people are always repeating themselves - don't be put off if the words sound funny at times: just keep right on, and by the time you've done writing you'll have produced your effect. (CW 3: 675) 
Yet after the initial impression that this writing is random, Mansfield, to her obvious dismay, realizes that there is indeed some kind of method, albeit one she clearly dislikes even more than the originally assumed arbitrariness.

We confess we read a good page or two before we realized what was happening. Then the dreadful fact dawned. We discovered ourselves reading in syncopated time. [...] Those who have heard the Southern Orchestra sing "It's me-it's me-it's me" or "I got a robe" will understand what we mean. "Melanctha" is negro music with all its maddening monotony done into prose; it is writing in real rag-time. Heaven forbid Miss Stein should become a fashion! (CW 3: 675-76)

As most previously quoted extracts from Mansfield's reviews, this one also covers several interesting issues at the heart of modernism. Mansfield is not a champion of Stein's "wandering discourse" (Armstrong 2005: 97), a thing clearly belonging to the various achievements of modernism. Instead she inclines towards what could be called the "waste-elimination in literature" (Armstrong 2005:131) and that, in an extension of Armstrong's argument about Pound and Imagism, in a way links her with Taylorism (2005: 131). On the one hand such an approach seems natural for the limited space of a short story for which "waste" could indeed be detrimental, but it is not solely that. Mansfield as a symbolist needs to rely on the singular effect of chosen words, objects and symbols, and she cannot risk their impact being weakened by unjustified repetitions or an excess of words.

I don't "just ramble on" you know, but this thing happened to just fix six and a half pages ... I'm a powerful stickler for form in this style of work. I hate the sort of licence that English people give themselves. ... to spread over and flop and roll it about. I feel as fastidious as though I wrote with acid. (Letters 1: 124; to J.M. Murry, [19 May 1913])

Also interesting is the reference to "negro" music or jazz which, as Armstrong shows, gained mixed opinions from the modernists, justifying his claim that apart from the tendency towards the appreciation of the "primitive" the "discourse of the 'counter-primitive' is another component of modernism" (2005: 149). While some leaned to jazz as the representation of the "primitive" pre-industrial they were trying to return to, others, as Mansfield's example shows, understood it as chaos and a "maddening" monotony, clearly not the right kind of "primitive" to embrace.

The final sentence of the review refers back to the often-repeated fear of something becoming "fashionable", and for that reason subject to endless imitation. So while Mansfield acknowledges Stein's "newness" and indeed originality, her own belief in perfectionism in formal matters and her clear dislike of the chaotic nature of jazz that she sees as analogous to Stein's work prevents her from liking it.

Yet arguably one of the most irritating of all the defects Mansfield perceives in the work of her fellow writers (and as evidenced by the letter to Gerhardi also 
in their "intricate conversations") is not in any way connected with the form of their writing but with the topics. A large number of books she was reviewing dealt with sex, and the way it was approached was not to Mansfield's liking at all. ${ }^{9}$ She claims that many of the writers are "dirty minded" (Letters 4: 270; to Dorothy Brett, [29 August 1921]) and attributes this, what she will later summarize as "fascinated pursuit of sex adventure" (Letters 4: 344; to Ottoline Morrell, [20 December 1921]), to the influence of Freud, or rather, to the popular interpretations of his findings which she derisively refers to as "psycho-analytical skimmings" (CW 3: 501). Mansfield's reviews and personal writings of 1919-1920, the period of her intense weekly reviewing for the Athenaeum, keep returning to the topic, uniformly condemning explicit depictions of sexuality, whether they appear to be justified or are clearly written simply as sensational pieces.

The former category is exemplified by M.P. Willcocks' The Sleeping Partner which deals with the consequences of an inadequate sexual education of adolescents. While Mansfield admits that "a large number of young persons have been severely handicapped" when their "healthy adolescent curiosity [was] treated as a disease so disgusting that they must be kept in the dark at all costs and never told the unpleasant - if sacred - truth," she also protests that "the progress towards light of these unfortunate ones makes heavy reading" and that there is hardly anything new to be told since "[w] hat we do not know about it is not for want of telling; it has been during the past few years the pet subject of our young writers to break a pen upon" (CW 3: 501).

The other case, the sensational novels are, according to her, even worse:

I'm sure I've read 20 novels this autumn by LADY writers that might all be called How I Lost My Virginity! If that wasn't bad enough - they never tell the truth - they always tell How I WISHED To Lose My Virginity, and in fact I don't believe they ever did lose it. (Letters 4: 45; to Sydney and Violet Schiff, [4 November 1920])

In this case, she again returns to the concept of authenticity and her imperative of a work of art telling the truth. As the example of other topics and reviews shows, even when she does not personally endorse the technique a writer employs, she does not condemn it provided the work is true to its chosen form and displays a determination to deal with its subject honestly. However, writing for gratification of one's own desires and pandering to the latest tastes and fashions, which the works she did condemn obviously do, is not, for Mansfield, a legitimate reason to write.

It would seem that she indeed had a very bad autumn batch of books to review, but her scorn was not limited to the conventional and now largely forgotten literary production; it was not even precipitated by a too big a number of novels to be processed in a short space of time. Her opinion on this topic is practically constant throughout her career and does not leave out even the top names of the modernist canon. Otherwise full of praise for his work, she criticized D.H. Lawrence for his 
obsession with sex, what she referred to as his "seeing sex in everything" (Letters 1: 261; to Beatrice Campbell, [4 May 1916]), and saw Joyce's work as "unhealthy in a peculiar way" (Letters 4, 232; to Anne Drey, [19 May 1921]).

Thus Mansfield, just like Woolf, was not a champion of open representations of sexuality, a fact that their respective works prove. Reasons for this artistic reticence, which is in stark opposition to her sexually adventurous life, are certainly manifold and include both personal and artistic ones. I will discuss only the latter as they are definitely more to the purpose of this paper.

Mansfield was a symbolist and the chosen method she described very early on in her career, influenced by her reading of Arthur Symons, explains why any depictions of sexual encounters in her works could not find a place:

The partisans of analysis describe minutely the state of the soul; the secret motive of every action itself. The partisans of objectivity - give us the result of this evolution sans describing the secret processes. They describe the state of the soul through the slightest gesture -i.e. realize flesh covered bones - which is the artist's method for me - in as much as art seems to me pure vision - I am indeed a partisan of objectivity. (Notebooks 1: 156)

Rather than analytical descriptions, she championed allusions, symbols and images, that, according to her, were more objective. She admirably confirms this in one sentence of her review of E.B.C. Jones's Quiet Interior, praising the author for trying to "keep faith with Truth rather than with Truth's ugly and stupid half-sister, Frankness" ( $C W$ 3: 694). She suggests that directness does not equal truthfulness and that sometimes the less straightforward ways may be more successful in conveying the ambiguity and complexity of the given situation. Mansfield's stories more often than not deal with sexuality too, yet they are far from sensationalist and attention seeking. They are often deeply disturbing and, even in all their indirectness, surprisingly bold.

To conclude, there seem to be two recurrent preoccupations that directly or indirectly permeate Mansfield's discussions of other writer's works, and they are the questions of authenticity and the place of tradition in the modern artistic production. Although not in agreement on this topic with other modernists in all the particulars, Mansfield shares with them this pursuit of the Romantic idea of authenticity and autonomy of a work of art in an era of mass culture. Both the unclear definition of what this authenticity actually is and the difficulty to attain it in a pure form indeed seem to have led the literature to an impasse from which it recovered with the postmodernist open acknowledgement of the impossibility of such a pursuit and with the embracing of the popular and mass production.

As to tradition, those reviews that generalize the deficiencies of modern literature often reflect Mansfield's contribution to the modernist discourse with respect to its role. She occupies a middle position believing that most bad writing of her era was caused either by too much tradition, or a complete abandonment of it. 
The Ark and the Flood belong to the old order, they are gone. [...] But if the Flood, the sky, the rainbow, or what Blake beautifully calls the bounding outline, be removed and if, further, no one thing is to be related to another thing, we do not see what is to prevent the whole of mankind turning author. (CW 3: 478)

Mansfield's call for a certain framework or at least some rules explains why she was at odds with Gertrude Stein's style of writing and in this respect, also with Virginia Woolf, who in her turn claimed that "there is no limit to the horizon, and [...] nothing - no 'method', no experiment, even of the wildest - is forbidden, but only falsity and pretence" (Woolf "Modern Fiction", n.p.). Mansfield would certainly agree with Woolf with respect to "falsity and pretence," but otherwise would probably reject her commendation of wildest experiments and methods enabling the apocalyptic "whole mankind turning author". She needed and cherished the "bounding outline", respected order and fastidiousness in art and acknowledged the necessity of having some connection with tradition. For her, just like for Eliot, art cannot live in a vacuum; no matter how innovative, every new work incorporates itself into the body of those written before, alters their pre-existing order so that "the relations, proportions, values of each work of art toward the whole are readjusted" and create some kind of "conformity between the old and the new," understanding that "the past [is] altered by the present as much as the present is directed by the past" (Eliot 1921: n.p.).

\section{Notes}

1 Such is the case of Bradbury and McFarlane's influential Modernism, A Guide to European Literature 1890-1930; Levenson's A Genealogy of Modernism: A Study of English Literary Doctrine 1908-1922; North's Reading 1922: A Return to the Scene of the Modern; Morrisson's The Public Face of Modernism: Little Magazines, Audiences and Reception, 1905-1920; Scholes' Paradoxy of Modernism to name but a few. Goldman's Modernism 1910-1945: Image to Apocalypse, which, although its professed aim is to "address the main literary transitions in the first half of the $20^{\text {th }}$ century" (xi), includes Katherine Mansfield only among "legions more to add", having previously named as "giants": James Joyce, Virginia Woolf, W.B. Yeats, Ezra Pound, Gertrude Stein, T.S. Eliot, H.D., William Carlos Williams, Wyndham Lewis and Wallace Stevens.

2 The monographs on Mansfield include for example Kaplan's Katherine Mansfield and the Origins of Modernist Fiction; Smith's Katherine Mansfield and Virginia Woolf: A Public of Two and Katherine Mansfield: A Literary Life; Meyers' Katherine Mansfield a Darker View; Kimber's Katherine Mansfield: The View from France, McDonnell's Katherine Mansfield and the Modernist Marketplace: At the Mercy of the Public, Jones's Katherine Mansfield The Story-Teller.

3 For discussions of Katherine Mansfield's reviews see Hanson (1987), Smith (2009), McDonnell (2010).

$4 \quad$ On the relationship between the two, see Séllei (1994) and Smith (1999).

5 Reviews of Virginia Woolf's "Kew Gardens" and Joseph Conrad's The Arrow of Gold.

$6 \quad$ Review of Sir Harry Johnston's The Gay-Dombey's. 
$7 \quad$ "The Stale and the Fresh," review of Jerome K. Jerome's All Roads Lead to Calvary and Beatrice Kean Seymour's Invisible Tides.

$8 \quad$ For a more detailed discussion of Mansfield's critique of war novels see Kaščáková (2013).

$9 \quad$ For a more detailed discussion of this topic see Kaščáková (2015).

\section{References}

Armstrong, Tim (2005) Modernism. Cambridge: Polity Press.

Bourdieu, Pierre (1984) Distinction: A Social Critique of the Judgment of Taste. Trans. Richard Nice. Cambridge: Harvard University Press.

Bradbury, Malcolm and James McFarlane (eds.) (1991) Modernism:, A Guide to European Literature 1890-1930. London: Penguin Books.

Eliot, T.S. (1921) "Tradition and the Individual Talent." The Sacred Wood. Bartleby.com, 1996. Accessed on 29 November 2013.

Garrity, Jane (2003) Stepdaughters of England: British Women Modernists \& the National Imaginary. Manchester: Manchester University Press.

Goldman, Jane (2004) Modernism 1910-1945: Image to Apocalypse. Basingstoke: Palgrave Macmilan.

Hanson, Clare (1987) The Critical Writings of Katherine Mansfield. New York: St. Martin's Press. Jones, Kathleen (2010) Katherine Mansfield The Story-Teller. Edinburgh: Edinburgh University Press.

Kaplan, Sydney Janet (1991) Katherine Mansfield and the Origins of Modernist Fiction. Ithaca, New York: Cornell University Press.

Kaščáková, Janka (2013) “"The greatest of all garden parties’: the Great War, Memory and Cultural Myths in Katherine Mansfield's Critical Writing." American and British Studies Annual 6: 88-99.

Kaščáková, Janka (2015) “'For all Parisians are more than half-': Stereotypes and Physical Love in Katherine Mansfield's Writing”. In: Davison, Claire and Gerri Kimber (eds.) Katherine Mansfield's French Lives. Leiden: Brill, 81-91.

Kimber, Gerri (2008) Katherine Mansfield: The View from France. Bern: Peter Lang.

Kimber, Gerri and Angela Smith (eds.) (2014) The Edinburgh Edition of the Collected Works of Katherine Mansfield. Volume 3. Edinburgh: Edinburgh University Press.

Levenson, Michael H. (1984) A Genealogy of Modernism: A Study of English Literary Doctrine 1908-1922. Cambridge: Cambridge University Press.

McDonnell, Jenny (2010) Katherine Mansfield and the Modernist Marketplace: At the Mercy of the Public. Basingstoke: Palgrave Macmillan.

Meyers, Jeffrey (2002) Katherine Mansfield a Darker View. New York: Cooper Square Publishers. Print.

Morrisson, Mark S. (2001) The Public Face of Modernism: Little Magazines, Audiences and Reception, 1905-1920. Madison: University of Wisconsin Press.

North, Michael (1999) Reading 1922: A Return to the Scene of the Modern. New York: Oxford University Press.

O'Connor, Frank (1963) The Lonely Voice. A Study of the Short Story. Cleveland, OH: World Publishing.

O'Sullivan, Vincent and Margaret Scott (eds.) (1984-2008) The Collected Letters of Katherine Mansfield. 5 vols. Oxford: Clarendon Press.

Scholes, Robert (2006) Paradoxy of Modernism. New Haven: Yale University Press.

Scott, Margaret (ed.) (1997) The Katherine Mansfield Notebooks. 2 vols. Canterbury \& Wellington: Lincoln University Press and Daphne Brasell Associates.

Séllei, Nóra (1994) Katherine Mansfield and Virginia Woolf: A Personal and Professional Bond. Bern: Peter Lang. 
Smith, Angela (1999) Katherine Mansfield and Virginia Woolf: A Public of Two. Oxford: Clarendon Press.

Smith, Angela (2000) Katherine Mansfield: A Literary Life. Basingstoke: Palgrave Macmillan.

Smith, Angela (2009) "GUTS - Katherine Mansfield as a Reviewer". Katherine Mansfield Studies, 1: $3-18$.

Woolf, Virginia (2008) "The Art of Fiction." The Essays of Virginia Woolf, Vol. 4, 1925-1928. Mariner Books.

Woolf, Virginia. "Middlebrow." The Death of the Moth, and other essays. eBooks @ Adelaide.

Web. Accessed on 27 November 2013.

Woolf, Virginia. "Modern fiction." The Common Reader. eBooks @ Adelaide. Web. Accessed on 27 November 2013.

JANKA KAŠČÁKová, a Senior Lecturer in English at Catholic University in Ružomberok, Slovakia, is the author of several articles and book chapters on both Katherine Mansfield and J. R. R. Tolkien. She is the co-editor of Middle-Earth and Beyond: Essays on the World of J. R. R. Tolkien (2010), Does it Really Mean That: Interpreting the Literary Ambiguous (2011), Katherine Mansfield and Continental Europe: Connections and Influences (2015) and the translator of a volume of Katherine Mansfield's stories into Slovak.

Address: Janka Kaščáková, PhD., Department of English Language and Literature, Faculty of Arts and Letters, Catholic University in Ružomberok, Hrabovská cesta 1, 03401 Ružomberok, Slovakia. [email: janka.kascakova@ku.sk] 
